\title{
BLACK-FOOTED FERRET HOME RANGES IN CONATA BASIN, SOUTH DAKOTA
}

\author{
Travis M. Livieri1 ${ }^{1,2}$ and Eric M. Anderson ${ }^{1}$
}

\begin{abstract}
We estimated annual home ranges and core areas of black-footed ferrets (Mustela nigripes) in Conata Basin, South Dakota, by collecting 834 locations of 28 ferrets (20 females, 8 males) through spotlighting from October 1997 to September 2000. Area-per-observation curves showed that a minimum of 23 locations were needed to estimate fixedkernel home-range size. Mean 95\% and 50\% fixed-kernel annual home-range sizes of females (95\%: $64.7 \mathrm{ha}, \mathrm{SE}=11.6$; $50 \%$ : 12.7 ha, $\mathrm{SE}=3.0)$ were significantly smaller and less variable than those of males $(95 \%: 131.8$ ha, $\mathrm{SE}=40.3 ; 50 \%$ : $35.6 \mathrm{ha}, \mathrm{SE}=16.5)$. Minimum convex polygon home-range estimates also differed between females (41.9 ha, $\mathrm{SE}=6.5 \mathrm{ha})$ and males ( $86.3 \mathrm{ha}, \mathrm{SE}=21.3$ ). Females' ranges were consistently less variable than males' ranges, regardless of the homerange estimator used. Female home-range size was negatively related to male density $\left(r^{2}=0.433\right)$, and male home-range size was positively associated with age $\left(r^{2}=0.671\right)$. Intersexual overlap and intrasexual exclusivity of home ranges was evident, suggesting that ferrets conform to a typical mustelid spacing pattern. Core use areas (50\% fixed-kernel ranges) had significantly higher black-tailed prairie dog (Cynomys ludovicianus) densities than $95 \%$ areas $(t=5.17, P=0.014)$, suggesting that core areas are located in areas of higher prairie dog densities. Relative to other mustelids, black-footed ferrets have considerably smaller home ranges.
\end{abstract}

Resumen.-Estimamos las áreas de actividad y los núcleos de actividad anuales de los hurones de patas negras (Mustela nigripes) en la Cuenca Conata, Dakota del Sur a través de la colecta de 834 localizaciones de 28 hurones (20 hembras, 8 machos) mediante el uso de reflectores durante octubre de 1997 - septiembre de 2000. Las curvas del área por observación mostraron que se necesitaba un mínimo de 23 localizaciones para estimar el tamaño del área de actividad mediante el estimador fijo de kernel. En promedio el $95 \%$ y el $50 \%$ del tamaño anual del área de actividad de acuerdo con el estimador fijo de kernel en las hembras (95\%: $64.7 \mathrm{ha}, \mathrm{EE}=11.6 ; 50 \%$ : $12.7 \mathrm{ha}$, $\mathrm{EE}=3.0$ ) fue significativamente más pequeño y menos variable que el de los machos (95\%: 131.8 ha, $\mathrm{EE}=40.3 ; 50 \%: 35.6$ ha, $\mathrm{EE}=16.5)$. Los estimados del área de actividad del polígono convexo mínimo también difirieron entre las hembras (41.9 ha, EE = 6.5 ha) y los machos (86.3 ha, $\mathrm{EE}=21.3 \mathrm{ha}$ ). Las áreas de las hembras fueron consistentemente menos variables que las de los machos, independientemente del método utilizado para estimar el área de actividad. El tamaño del área de actividad de las hembras se relacionó negativamente con la densidad de los machos $\left(r^{2}=0.433\right)$, mientras que el tamaño del área de actividad de los machos se asoció positivamente con la edad $\left(r^{2}=0.671\right)$. Fue evidente la superposición intersexual y la exclusividad intrasexual de las áreas de actividad, lo cual sugiere que los hurones se adaptan a un modelo espacial típico de mustélidos. Las áreas núcleo de actividad (50\% estimador fijo de kernel) tuvieron densidades mucho más elevadas de perros llaneros de cola negra (Cynomys ludovicianus) que el 95\% de las áreas $(t=5.17, P=0.014)$, lo cual sugiere que las áreas núcleo se encuentran en áreas con densidades más elevadas de perros llaneros. En comparación con otros mustélidos, los hurones de patas negras tienen áreas de actividad considerablemente más pequeñas.

Black-footed ferrets (Mustela nigripes) are federally endangered mustelids that rely on prairie dogs (Cynomys spp.) for food and shelter (Biggins et al. 2006c). Because of their secretive, nocturnal habits and extreme rarity, only 2 populations of ferrets were studied before their extinction in the wild in 1987. The first population was studied from 1964 to 1974 in Mellette County, South Dakota, and it subsequently disappeared in 1974. The second population, near Meeteetse, Wyoming, suffered a catastrophic decline due to disease (Forrest et al. 1988). The last 18 individuals were rescued from the wild, and a successful captive breeding program began
(Miller et al. 1996). Enough "excess" ferrets were produced in captivity that reintroductions into the wild began in 1991 and continue to the present in Mexico, Canada, and 8 states (Lockhart et al. 2006, Jachowski and Lockhart 2009). Ferrets only occupy prairie dog colonies, and, until recent years, the large, wild populations necessary to investigate spatial use of prairie dog colonies by ferrets did not exist. In planning prairie dog reserves and managing for blackfooted ferret reintroduction, an understanding of ferret spatial use is useful in estimating the size of prairie dog colonies needed to sustain a viable population of wild ferrets.

${ }^{1}$ College of Natural Resources, University of Wisconsin-Stevens Point, Stevens Point, WI 54481.

2Present address: Prairie Wildlife Research, Box 308, Wellington, CO 80549. E-mail: tlivieri@prairiewildlife.org 
There are few previously published estimates of ferret home-range size. The majority of previous data on ferret movements came from the Meeteetse, Wyoming, population, which survived on white-tailed prairie dogs (Cynomys leucurus). Tileston and Lechleitner (1966) found that black-tailed prairie dog (Cynomys ludovicianus) colonies have a higher prairie dog density than white-tailed prairie dog colonies; hence ferret movement estimates from Meeteetse may not apply in South Dakota, which contains only black-tailed prairie dogs. At Meeteetse, snow tracking revealed that a young female used 16.0 ha from December to March and was overlapped by a male that used 136.6 ha (Forrest et. al 1985). Further snow tracking found ferret minimum convex polygon (MCP; Mohr 1947) activity areas averaging 23.9 ha over 3 nights (Richardson et al. 1987). Biggins et al. (1985) used MCP to estimate that a radio-collared female used 12.6 ha and a radio-collared male used 27.5 ha over a 15 -day period; the female continued to use an MCP range of 53 ha after the first 15 days. Fagerstone (1987) reported monthly (Aug-Dec) MCP areas for a radio-collared juvenile female and an adult male as 1.2-106.8 ha and 13.1-257.8 ha, respectively. Fagerstone and Biggins (2011) found weekly activity areas of 17.2 ha for 3 adult female ferrets and 117.4 ha for 2 adult male ferrets. In Conata Basin, South Dakota, Jachowski et al. (2010) reported 95\% fixed-kernel utilization distribution home-range sizes of ferrets from May to October, finding mean home ranges of 56.3 ha for 6 females and 128.3 ha for 3 males.

Evidence from Meeteetse and South Dakota suggests that male black-footed ferrets have larger home ranges than females, a pattern often observed in solitary, polygynous animals (Baker 1978, Sandell 1989). Forrest et al. (1985) suggested that male ferrets selected home ranges primarily to maximize access to females and only secondarily to maximize food resources. Female home-range sizes, however, appeared more related to the area needed to meet energy needs of dams plus their dependent young. Ferrets likely conform to a typical mustelid spacing pattern with intersexual overlap and intrasexual exclusion (Powell 1979, Forrest et al. 1985). Richardson et al. (1987) reported spatial, but not temporal, overlap of ferret $100 \%$ MCP activity areas during winter months at Meeteetse, but activity centers were discrete. Jachowski et al. (2010) found that
95\% fixed-kernel range overlap of female ferrets ranged from $0 \%$ to $42 \%$.

In addition to gender, several biological and environmental factors may influence blackfooted ferret home-range size. Captive-born ferrets released into the wild may exhibit homerange characteristics different from their wildborn counterparts due to lingering influences from captivity, greater exploratory behaviors, and increased time spent aboveground (Biggins et al. 1999). Age may also influence home-range size. Biggins et al. (2006a) postulated that older males maintain a higher social status and competitively exclude younger males. If a ferret occupies only one prairie dog colony throughout the year, then colony size may also influence home-range size. Ferrets have been observed year-round on prairie dog colonies as small as 17.8 ha in Conata Basin (T. Livieri unpublished data). Hillman et al. (1979) reported ferrets occupying colonies as small as 14 ha for 6 months in Mellette County, South Dakota. Forrest et al. (1985) observed that white-tailed prairie dog colonies $>180$ ha were continuously occupied, while smaller colonies were used seasonally or not at all. In many solitary carnivores, density of conspecifics is strongly negatively correlated with home-range size, and density appears to be related to prey abundance (Sandell 1989). Thus, density of ferrets as a function of prairie dog abundance may influence home-range size. Prairie dog density may influence home-range size of ferrets as suggested by Jachowski et al. (2010), although the relationship is likely affected by territoriality as prairie dog densities increase (Biggins et al. 2006d).

The objectives of this study were to estimate annual black-footed ferret home-range size for the first time, identify factors that may influence home-range size, and estimate inter- and intrasexual home-range overlap. We used ferret locations from Conata Basin in southwestern South Dakota to estimate annual home-range size, to calculate overlap, and to examine the effects of gender, origin (captive-born or wild-born), age (1 year old or $>1$ year old), prairie dog colony size, prairie dog density, inter- and intrasexual ferret density, and number of locations on range size.

\section{Methods}

Study Area

Conata Basin is a 29,000-ha mixed-grass prairie located on the Buffalo Gap National 
Grassland in southwestern South Dakota. This land is administered by the USDA Forest Service and is adjacent to Badlands National Park. Vegetation is dominated by western wheatgrass (Agropyron smithii), buffalograss (Buchloe dactyloides), and blue grama (Bouteloua gracilis). Primary land uses are cattle grazing and recreation. In 1999, the area contained 4050 ha of prairie dog colonies, mapped by driving the perimeter of each colony with a differentially corrected GPS and visualized by importing the data to ArcView 3.1 (ESRI, Redlands, CA). Size of 195 prairie dog colonies in the study area averaged 28.4 ha $(\mathrm{SE}=5.2$, range $0.1-656.8 \mathrm{ha}$; Livieri 2007). Black-footed ferrets were extirpated from South Dakota by 1974 (Fagerstone 1987, Clark 1989, Lockhart et al. 2006). Reintroductions into South Dakota began in 1994, and 146 captive-born kits were reintroduced into Conata Basin during 1996-1999 (Livieri 2006). The ferret population in this study was composed of released captive-born individuals and their wild-born offspring, totaling approximately 200 individuals annually from 2000-2006.

\section{Location Data}

Black-footed ferrets are primarily nocturnal and were located by spotlighting on prairie dog colonies (Clark et al. 1983, Campbell et al. 1985, Biggins et al. 2006b). Locations were recorded using a differentially corrected GPS with a location error of $<1 \mathrm{~m}$. All animals were marked with passive integrated transponder (PIT) tags (Fagerstone and Johns 1987, Stoneberg 1996) prior to release or shortly after birth in the wild. Capture and handling protocols were developed as described in Gannon et al. (2007) and were approved by the University of Wisconsin-Stevens Point Institutional Animal Care and Use Committee. Ferrets were identified using a passive reader at the occupied prairie dog burrow. Spotlighting occurred throughout the year, with the exception of June, and the most effort expended was from September to January during dispersal. Ferret kits typically become independent of their mothers in September-October and disperse to find their own territories (Henderson et al. 1969, Biggins et al. 1986).

Black-footed ferret density on a prairie dog colony was estimated as the maximum number of ferrets occupying the same colony at any time between 1 October and 30 September the following year. We explored the relationship between home-range size and prairie dog density using the GPS locations of all prairie dog burrows of one colony overlaid with ferret home ranges. Prairie dog burrows were mapped using differentially corrected GPS units and classified as active or inactive based upon presence of fresh scat (Biggins et al. 1993). Active prairie dog burrow numbers within each ferret home range were converted to number of prairie dogs to estimate prairie dog density following the calculations of Biggins et al. (1993; prairie dog density $=0.179 \times$ active burrow density/0.566).

\section{Data Analysis}

Ferrets that used multiple prairie dog colonies in a year were removed from analysis because such movement suggests a nonstationary home range. We used an area-per-observation curve (Odum and Kuenzler 1955) — a graph of cumulative home-range size as successive observations are added-to estimate the minimum number of locations needed to assess home-range size. We used 12 hours as the time to independence (TTI) between successive locations based upon our observations of nightly movements up to $830 \mathrm{~m}$ and movement rates up to $519 \mathrm{~m}$ per hour. Locations within the first 30 days postrelease or postdispersal were eliminated to allow for establishment of a territory after the initial exploratory/dispersal period; hence, the data for each animal spanned 1 October-30 September. We used only ferrets that had a minimum of one location in at least 6 different months to ensure accurate representation of annual home ranges.

Home-range size was estimated using 3 estimators: fixed kernel (FK) at the $95 \%$ and $50 \%$ contours (Worton 1989) and 100\% MCP (Mohr 1947) calculated with the Animal Movement Extension v2.0 (Hooge et al. 1999) in ArcView 3.1. Fixed-kernel estimates used least-squares cross-validation, considering the $95 \%$ contour as the extent of the range and the $50 \%$ contour as the core use area. Because ferrets only use prairie dog colonies (Biggins et al. 2006c), resulting home ranges were clipped to exclude areas outside of prairie dog colonies (Livieri 2007). We calculated the overlap of home ranges for all methods (95\% FK, 50\% FK, MCP) within and between sexes as a percentage of each animal's range. Only ferrets with core areas that overlapped or whose $95 \%$ FK ranges overlapped by more than $1 \%$ were reported. Because 


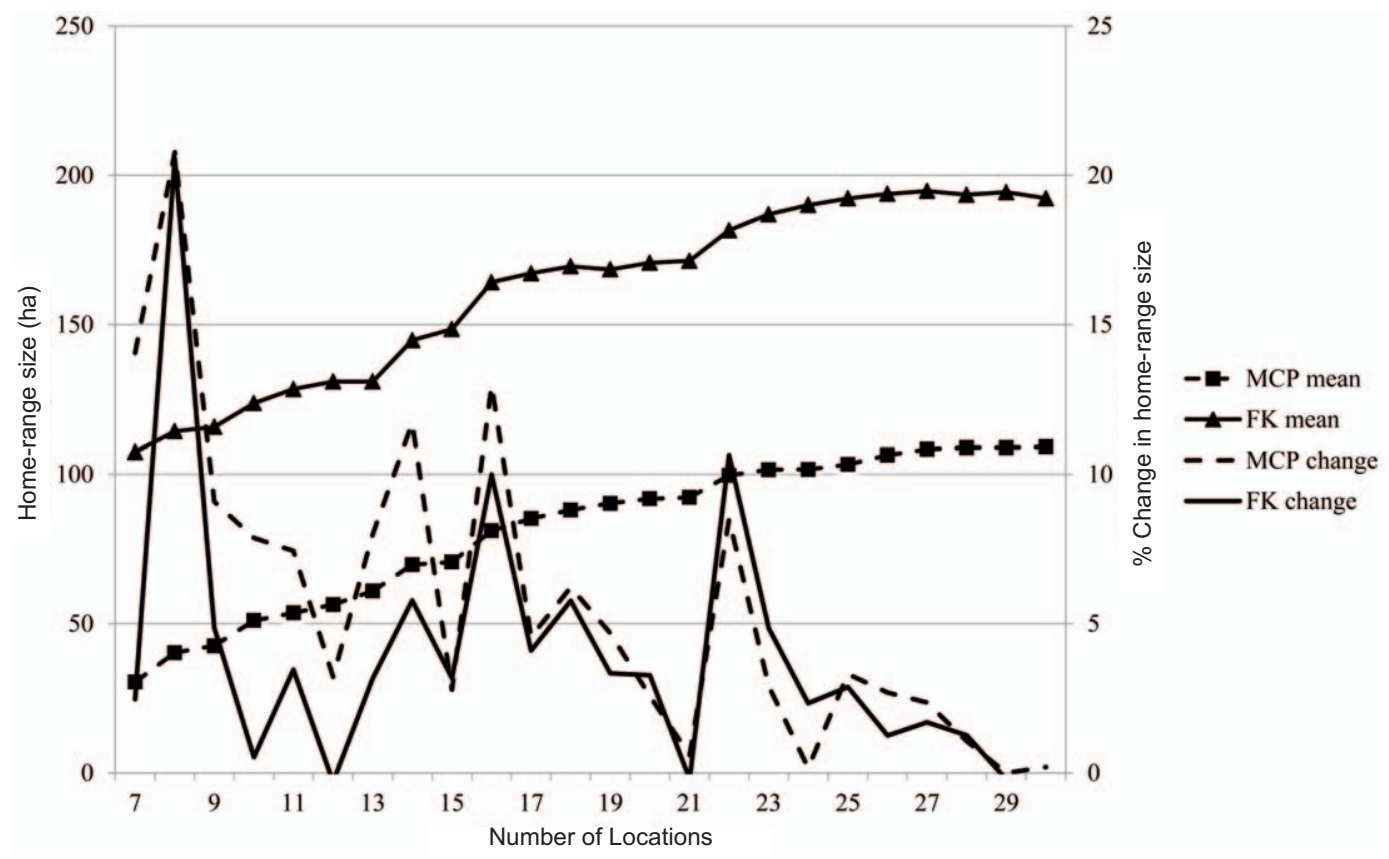

Fig. 1. Area-per-observation curves for black-footed ferret home ranges $(n=8)$ in Conata Basin, South Dakota, for 95\% fixed-kernel (FK) and $100 \%$ minimum convex polygon (MCP) home-range estimators.

not all located ferrets were used in home-range analyses, and because some ferrets may have avoided detection, the estimated degree of overlap is likely an underestimate of the actual overlap.

Black-footed ferret home-range estimates were tested for normality using Shapiro-Wilk W (Shapiro and Wilk 1965), normalized using natural logarithm transformations when necessary, and all analyses followed Zar (1996). A 2-way ANOVA with a Tukey-Kramer multiple comparison test was used to compare homerange size between gender and origin (captive or wild born). An $F$ test was used to compare variance in home-range size between sexes. A paired $t$ test was used to compare density of prairie dogs within the core area $(50 \% \mathrm{FK})$ to the corresponding prairie dog density in the $95 \%$ FK outside of the core area. A significance level of $\alpha=0.10$ was used for all analyses to reduce type II errors common with small sample sizes. Multiple linear regression was used to determine factors that may influence blackfooted ferret home-range size (male density, female density, total ferret density, colony size, and age). Models were evaluated using $r^{2}$, Akaike's information criterion corrected for small sample size $\left(\mathrm{AIC}_{c}\right.$; Burnham and Anderson 2002), and Akaike weights. Models were considered competitive if they had AIC evidence ratio (Burnham and Anderson 2002) values within 3 units of the lowest valued model and if $r^{2}$ were high.

\section{RESULTS}

Using location data from 8 resident ferrets (7 female, 1 male) with $\geq 30$ locations and 12 hours as the TTI of consecutive locations, 23 independent locations were needed to adequately describe ferret home ranges. The mean percent change in 95\% fixed-kernel home-range size for successive locations beyond 23 showed $<3 \%$ increase in home-range size for each additional location (Fig. 1). If an animal had $\geq 23$ independent locations, we used all locations for home-range estimates, regardless of their independence because TTI has little influence on kernel or MCP estimates (Swihart and Slade 1997). Others have also reported that autocorrelated locations do not influence homerange estimates or provide a more accurate estimate (Andersen and Rongstad 1989, Gese et al. 1990, Reynolds and Laundre 1990, DeSolla et al. 1999). For MCP, home-range size 
TABLE 1. Evaluation of competing models for predicting female black-footed ferret (BFF) home-range size in Conata Basin, South Dakota, using several estimators (95\% fixed kernel, 50\% fixed kernel, and 100\% minimum convex polygon). Bold variables are positively associated with home-range size, and italicized variables are negatively related.

\begin{tabular}{|c|c|c|c|c|c|}
\hline Model & $\mathrm{AIC} c$ & $\Delta \mathrm{AIC} c$ & $\begin{array}{l}\text { Akaike } \\
\text { weight }\end{array}$ & $\begin{array}{l}\text { Evidence } \\
\quad \text { ratio }\end{array}$ & $r^{2}$ \\
\hline \multicolumn{6}{|l|}{$95 \%$ Fixed kernel } \\
\hline Male density & -17.63 & 0.00 & 0.290 & & 0.433 \\
\hline Male density + Colony size & -16.35 & 1.28 & 0.153 & 1.90 & 0.484 \\
\hline Colony size & -15.82 & 1.81 & 0.118 & 2.47 & 0.379 \\
\hline Male density + Age & -15.03 & 2.60 & 0.079 & 3.66 & 0.449 \\
\hline Total BFF density + Colony size & -15.00 & 2.63 & 0.078 & 3.72 & 0.448 \\
\hline Total BFF density & -14.92 & 2.71 & 0.075 & 3.87 & 0.351 \\
\hline \multicolumn{6}{|l|}{$50 \%$ Fixed kernel } \\
\hline Male density & -8.40 & 0.00 & 0.459 & & 0.482 \\
\hline Male density + Colony size & -6.25 & 2.15 & 0.157 & 2.93 & 0.508 \\
\hline Male density + Age & -5.97 & 2.43 & 0.136 & 3.38 & 0.501 \\
\hline \multicolumn{6}{|l|}{$100 \%$ Minimum convex polygon } \\
\hline Male density & -22.57 & 0.00 & 0.353 & & 0.418 \\
\hline Total BFF density & -20.29 & 2.28 & 0.113 & 3.13 & 0.348 \\
\hline Male density + Colony size & -20.29 & 2.29 & 0.112 & 3.14 & 0.443 \\
\hline Male density + Age & -19.43 & 3.15 & 0.073 & 4.83 & 0.419 \\
\hline
\end{tabular}

plateaued (<3\% change) after 27-28 locations, suggesting that 23 locations may underestimate total home-range size by the MCP technique.

Spotlighting of black-footed ferrets occurred on 239 nights from 1 October 1997 to 30 September 2000. Three-hundred and six individual ferrets (160 females, 146 males) were identified a total of 4540 times. The screening criteria of $\geq 23$ independent locations for home-range estimation was met by 28 ferrets ( 4 adult females, 16 juvenile females, 3 adult males, 5 juvenile males) on 6 prairie dog colonies with an average of 29.8 ( $\mathrm{SE}=1.1)$ locations per ferret (range 23-46). The majority of locations (80\%) were collected from July to December during litter emergence and ferret dispersal (Hillman and Clark 1980, Clark 1989).

The 95\% FK home ranges for males and females were significantly different $\left(F_{1,24}=\right.$ $4.39, P=0.047$ ) with male ranges (131.8 ha, $\mathrm{SE}=40.3 \mathrm{ha})$ averaging twice the size of female ranges (64.7 ha, $\mathrm{SE}=11.6 \mathrm{ha})$. Estimates ranged from 13.9 to 202.7 ha for females and from 31.7 to 361.4 ha for males. Core use areas $(50 \%$ FK) for males (35.6 ha, $\mathrm{SE}=16.5 \mathrm{ha})$ were nearly 3 times the size of female ranges $(12.7$ ha, $\mathrm{SE}=3.0 ; F_{1,24}=4.67, P=0.041$ ). They ranged from 1.7 to 56.0 ha for females and from 3.9 to 142.9 ha for males. Mean MCP areas were 41.9 ha $(\mathrm{SE}=6.5)$ for females and $86.3 \mathrm{ha}$ $(\mathrm{SE}=21.3)$ for males $\left(F_{1,24}=5.22, P=0.031\right)$. Estimates for MCP home ranges varied from 9.0 to 119.1 ha for females and from 20.2 to 180.7 ha for males. There were no discernible differences in size between home ranges of captive- and wild-born ferrets by either the $95 \%$ FK method $\left(F_{1,24}=1.06, P=0.313\right)$, the $50 \%$ FK method $\left(F_{1,24}=1.22, P=0.280\right)$, or the MCP method $\left(F_{1,24}=0.29, P=0.593\right)$. Regardless of the estimator used, female home ranges were consistently less variable than male ranges $\left(95 \% \mathrm{FK}: F_{7,19}=0.206, P=0.003\right.$; $50 \%$ FK: $F_{7,19}=0.084, P<0.001 ;$ MCP: $\left.F_{7,19}=0.231, P=0.005\right)$. Female core use areas $(50 \% \mathrm{FK})$ occupied a smaller proportion of female $95 \%$ FK home ranges $(17.4 \%)$ than male core use areas on male ranges $(22.3 \%)$, although the difference was not significant $\left(F_{1,26}=1.66, P=0.109\right)$.

In the absence of prairie dog density as a variable, multiple linear regression models revealed that increasing female black-footed ferret home-range size was most strongly associated with decreasing male density for all 3 models (95\% FK, 50\% FK, MCP; Table 1). A positive association with colony size was also present in the top-competing models for the $95 \%$ and $50 \%$ FK. For males, age alone was positively related to home-range size for $95 \%$ FK and MCP models (Table 2). The competing 50\% FK models identified colony size and age as positively related to male home-range size and negatively related to densities of males, females, and combined genders.

Intrasexual overlap of annual home ranges (95\% FK and MCP) was evident in both genders, although core areas had very little intrasexual overlap (Table 3). Males overlapped a 
TABLE 2. Evaluation of competing models for predicting male black-footed ferret (BFF) home-range size in Conata Basin, South Dakota, using several estimators (95\% fixed kernel, 50\% fixed kernel, and 100\% minimum convex polygon). Bold variables are positively associated with home-range size, and italicized variables are negatively related.

\begin{tabular}{|c|c|c|c|c|c|}
\hline Model & $\mathrm{AIC}_{c}$ & $\Delta \mathrm{AIC}_{c}$ & $\begin{array}{l}\text { Akaike } \\
\text { weight }\end{array}$ & $\begin{array}{l}\text { Evidence } \\
\text { ratio }\end{array}$ & $r^{2}$ \\
\hline \multicolumn{6}{|l|}{$95 \%$ Fixed kernel } \\
\hline Age & -6.94 & 0.00 & 0.334 & & 0.671 \\
\hline Male density & -4.13 & 2.81 & 0.082 & 4.07 & 0.532 \\
\hline Age + Colony size & -4.05 & 2.89 & 0.079 & 4.24 & 0.675 \\
\hline Male density + Age & -3.99 & 2.95 & 0.077 & 4.36 & 0.673 \\
\hline Total BFF density + Age & -3.96 & 2.98 & 0.075 & 4.43 & 0.672 \\
\hline Female density + Age & -3.95 & 2.99 & 0.075 & 4.46 & 0.671 \\
\hline Female density + Colony size & -3.92 & 3.02 & 0.074 & 4.53 & 0.670 \\
\hline \multicolumn{6}{|l|}{$50 \%$ Fixed kernel } \\
\hline Female density + Colony size & -6.08 & 0.00 & 0.183 & & 0.851 \\
\hline Total BFF density + Colony size & -6.01 & 0.08 & 0.176 & 1.04 & 0.849 \\
\hline Age + Colony size & -5.65 & 0.43 & 0.147 & 1.24 & 0.842 \\
\hline Colony size & -5.19 & 0.89 & 0.117 & 1.56 & 0.757 \\
\hline Male density + Colony size & -4.88 & 1.21 & 0.100 & 1.83 & 0.826 \\
\hline Age & -3.96 & 2.12 & 0.063 & 2.89 & 0.717 \\
\hline Female density + Age & -3.41 & 2.67 & 0.048 & 3.80 & 0.792 \\
\hline \multicolumn{6}{|l|}{$100 \%$ Minimum convex polygon } \\
\hline Age & -5.73 & 0.00 & 0.305 & & 0.536 \\
\hline Male density + Age & -3.32 & 2.41 & 0.092 & 3.34 & 0.569 \\
\hline Male density & -3.10 & 2.63 & 0.082 & 3.73 & 0.355 \\
\hline Total BFF density + Age & -2.79 & 2.94 & 0.070 & 4.36 & 0.539 \\
\hline Age + Colony size & -2.74 & 2.99 & 0.068 & 4.46 & 0.536 \\
\hline Female density + Age & -2.73 & 3.00 & 0.068 & 4.48 & 0.536 \\
\hline Colony size & -2.69 & 3.04 & 0.067 & 4.58 & 0.321 \\
\hline
\end{tabular}

TABLE 3. Intra- and intersexual overlap in black-footed ferret home ranges in Conata Basin, South Dakota, using $50 \%$ fixed kernel (FK), 95\% fixed kernel, and $100 \%$ minimum convex polygon (MCP) estimators.

\begin{tabular}{|c|c|c|c|c|c|}
\hline Estimator & $\%$ of home range & Overlapped by & $n$ & Mean $\%$ of home range & Range \\
\hline $50 \% \mathrm{FK}$ & Female & Female & 2 & 4.1 & $3.7-4.6$ \\
\hline $95 \% \mathrm{FK}$ & Female & Female & 18 & 15.6 & $1.0-34.0$ \\
\hline $100 \% \mathrm{MCP}$ & Female & Female & 10 & 13.2 & $3.4-31.0$ \\
\hline $50 \% \mathrm{FK}$ & Female & Male & 4 & 40.7 & $21.9-54.0$ \\
\hline $95 \% \mathrm{FK}$ & Female & Male & 11 & 65.6 & $8.7-100.0$ \\
\hline $100 \% \mathrm{MCP}$ & Female & Male & 9 & 60.1 & $16.1-100.0$ \\
\hline $50 \% \mathrm{FK}$ & Male & Female & 4 & 11.0 & $5.2-14.1$ \\
\hline $95 \% \mathrm{FK}$ & Male & Female & 11 & 30.5 & $2.7-57.3$ \\
\hline $100 \% \mathrm{MCP}$ & Male & Female & 9 & 26.9 & $11.0-51.1$ \\
\hline $50 \% \mathrm{FK}$ & Male & Male & 0 & - & - \\
\hline $95 \% \mathrm{FK}$ & Male & Male & 4 & 19.3 & $1.3-57.4$ \\
\hline $100 \% \mathrm{MCP}$ & Male & Male & 2 & 7.6 & $2.9-12.4$ \\
\hline
\end{tabular}

higher proportion of female ranges than females overlapped male ranges. Core areas for males had no intrasexual overlap, and only 2 unrelated females had core area intrasexual overlap, which suggests a high level of intrasexual territoriality. Home-range overlap was most likely underestimated, because several animals that were present within the range of another ferret did not meet the minimum number of locations for estimating their home ranges. These animals were excluded from the analysis.
In 1999, we mapped 21,800 prairie dog burrows (19,105 active; 2307 inactive; 388 plugged) on one prairie dog colony. The home ranges of 4 ferrets (3 females, 1 male) were overlaid on burrow distribution to estimate burrow density and prairie dog density per home range. There was no detectable relationship between prairie dog density and ferret home-range size for the $50 \%$ FK $\left(r^{2}=0.187, P=0.323\right), 95 \%$ FK $\left(r^{2}\right.$ $=0.175, P=0.329)$, or the $\mathrm{MCP}\left(r^{2}=-0.076\right.$, $P=0.469)$ home-range estimators. However, we found a significantly higher prairie dog 
density in $50 \%$ FK areas than in the surrounding $95 \% \mathrm{FK}$ areas $(t=5.17, P=0.014)$. Converting active burrow densities to number of prairie dogs (Biggins et al. 1993), the 95\% FK home range of 4 ferrets contained 948-3495 prairie dogs, which is considerably higher than the estimated 272.5-763 prairie dogs needed to sustain a ferret family (Biggins et al. 1993).

\section{Discussion}

In Conata Basin, home ranges of male blackfooted ferrets were significantly larger than those of females, which is consistent with previous findings (Biggins et al. 1985, Fagerstone 1987, Jachowski et al. 2010). The MCP estimates of 16.0 ha for a female ferret and 136.6 ha for a male ferret at Meeteetse (Biggins et al. 1985 ) and the 95\% fixed-kernel estimates of 56.3 ha for females and 128.3 ha for males at Conata Basin (Jachowski et al. 2010) both fell within the range of estimates we observed. Female home-range size was much more consistent than male home-range size. The disparity in variation is consistent with the explanations offered for the sexual difference in home-range size; females may select home ranges to maximize access to prey resources, whereas males may be maximizing access to females (Baker 1978, Sandell 1989, Miller et al. 1996).

We were unable to detect a relationship between prairie dog density and home-range size. Jachowski et al. (2010), investigating one of the same study colonies a decade after our fieldwork, reported a strong inverse relationship between female home-range size and active prairie dog burrows. This discrepancy between studies was likely due to either the lack of statistical power of our small sample $(n$ $=4$ ) or methodology differences. We clipped home ranges at colony edges to exclude areas that ferrets did not use, whereas Jachowski et al. (2010) included areas outside of prairie dog colonies. Unclipped ranges inflate the relationship between home-range size and densities of active burrow openings. However, we did determine that ferret activity within an individual's 50\% FK home range was clearly centered on areas of higher prairie dog density. The preference of ferrets for areas with higher prey density has also been demonstrated in Montana and South Dakota (Biggins et al. 2006c), although Forrest et al. (1985) found that white-tailed prairie dog burrow 
density did not appear to influence activity area size for 21 ferrets in Wyoming.

Age influenced male $95 \%$ FK and MCP home-range size, suggesting that older males may be more dominant and willing to travel farther to expand their breeding opportunities. They may also be successful at excluding younger males (Biggins et al. 2006a). Forrest et al. (1988) found that adult ferrets exhibited annual site fidelity, implying that established older animals can successfully defend their home ranges from intrusions by younger ferrets. Biggins et al. (2006c) also found that prior residency of ferrets imparted an advantage in selecting areas with higher burrow density (habitat quality) over newcomers.

Ferrets in Conata Basin appeared to conform to a typical mustelid spacing pattern of intersexual overlap and intrasexual exclusion (Powell 1979, Forrest et al. 1985), although there was some tolerance of intrasexual overlap at the 95\% FK and MCP levels. The high percentage of intrasexual overlap of female $95 \% \mathrm{FK}$ ranges (up to $34 \%$ ) was consistent with the maximum of $42 \%$ reported by Jachowski et al. (2010) and may reflect the close genetic relationship of adjacent females, who may be more tolerant of trespass by offspring. The high levels of overlap may also be an artifact of the home-range estimation method because the peripheral areas of an estimated home range typically have the least supporting data and, hence, are less likely to be biologically significant (Seaman et al. 1999). Intrasexual exclusion was much more apparent in the more intensively used $50 \%$ core areas where only 2 females overlapped slightly. None of the core areas of males overlapped. Intersexual overlap of female ranges by male ranges was greater than overlap of male ranges by female ranges, a likely consequence of males having larger ranges than females.

Ferguson and Lariviere (2004) suggested that mustelids generally occupy highly unpredictable environments and have relatively larger home ranges and lower population densities than other terrestrial carnivores. However, within the mustelids, black-footed ferrets occupy a far smaller home range than the comparably sized American marten (Martes americana) or European polecat (Mustela putorius). The long-tailed weasel (Mustela frenata), at a third of the weight of the ferret, occupies a home range of similar size (Table 4). The smaller home-range size of the black-footed ferret may be the consequence of having a single prey item that occupies essentially contiguous habitat. Fragmented habitat used by other mustelids, coupled with much more dispersed prey items, may lead to the disparity in range size (Gehring and Swihart 2004). Despite the small size of their ranges relative to the ranges of other mustelids, it appears that ferrets in Conata Basin occupy an area that contains significantly more prey than they may need, although high prairie dog densities may be related to other population vital rates such as survival and productivity (Biggins et al. 2006d). Planning for ferret reintroduction sites and reserves should incorporate homerange information for predicting the area needed to support a population of ferrets.

\section{ACKNOWLEDGMENTS}

Funding was provided by Badlands National Park, the University of Wisconsin-Stevens Point, the USDA Forest Service, the Zoological Society of Milwaukee County, and the World Wildlife Fund. USDA Forest Service-Wall Ranger District and Badlands National Park assisted with data collection. We are indebted to G. Plumb, W. Perry, D. Albertson, D. Sargent, G. Schroeder, B. Bessken, D. Biggins, J. Godbey, and R. Matchett for sharing insights and offering logistical support. We appreciate reviews by D. Biggins and D. Eads that improved the manuscript.

\section{Literature Cited}

Andersen, D.E., And O.J. Rongstad. 1989. Home-range estimates of red-tailed hawks based on random and systematic relocations. Journal of Wildlife Management 53:802-807.

BAKER, R.R. 1978. The evolutionary ecology of animal migration. Holmes and Meier, New York, NY.

Biggins, D.E., J.L. Godbey, T.M. Livieri, M.R. MAtchetT, AND B. Bibles. 2006a. Postrelease movements and survival of adult and young black-footed ferrets. Pages 191-200 in J.E. Roelle, B.J. Miller, J.L. Godbey, and D.E. Biggins, editors, Recovery of the black-footed ferret-progress and continuing challenges. U.S. Geological Survey Scientific Investigations Report 2005-5293. Available from: http://www.fort.usgs.gov/ Products/Publications/21665/21665.pdf

Biggins, D.E., J.L. Godbey, M.R. Matchett, L.R. HaneBury, T.M. LiviERI, AND P.E. Marinari. 2006b. Monitoring black-footed ferrets during reestablishment of free-ranging populations: discussion of alternative methods and recommended minimum standards. Pages 155-174 in J.E. Roelle, B.J. Miller, J.L. Godbey, and D.E. Biggins, editors, Recovery of the black-footed ferret-progress and continuing challenges. U.S. Geological Survey Scientific Investigations Report 
2005-5293. Available from: http://www.fort.usgs.gov/ Products/Publications/21610/21610.pdf

Biggins, D.E., J.L. Godbey, M.R. Matchett, and T.M. LIVIERI. 2006c. Habitat preferences and intraspecific competition in black-footed ferrets. Pages 129-140 in J.E. Roelle, B.J. Miller, J.L. Godbey, and D.E. Biggins, editors, Recovery of the black-footed ferretprogress and continuing challenges. U.S. Geological Survey Scientific Investigations Report 2005-5293. Available from: http://www.fort.usgs.gov/Products/ Publications/21572/21572.pdf

Biggins, D.E., J.M. LOCKHART, AND J.L. GODBEy. 2006d. Evaluating habitat for black-footed ferrets: revision of an existing model. Pages 143-150 in J.E. Roelle, B.J. Miller, J.L. Godbey, and D.E. Biggins, editors, Recovery of the black-footed ferret-progress and continuing challenges. U.S. Geological Survey Scientific Investigations Report 2005-5293. Available from: http://www.fort.usgs.gov/Products/Publications/ 21570/21570.pdf

Biggins, D.E., B.J. Miller, L.R. Hanebury, B. OAKLeaf A.H. Farmer, R. Crete, and A. Dood. 1993. A technique for evaluating black-footed ferret habitat. Pages 73-87 in J. Oldemeyer, D. Biggins, and B. Miller, editors, Management of prairie dog complexes for the reintroduction of the black-footed ferret. U.S Fish and Wildlife Service Biological Report 93-13, Washington, DC.

Biggins, D.E., M.H. Schroeder, S. Forrest, and L. RICHARDSON. 1985. Movements and habitat relationships of radio-tagged black-footed ferrets. Pages 11.1-11.17 in S.H. Anderson and D.B. Inkley, editors, Black-footed Ferret Workshop Proceedings. Wyoming Game and Fish Department, Cheyenne, WY.

1986. Activity of radio-tagged black-footed ferrets. Great Basin Naturalist Memoirs 8:135-140.

Biggins, D.E., A. Vargas, J.L. GodbeY, AND S.H. ANDERSON. 1999. Influence of prerelease experience on reintroduced black-footed ferrets (Mustela nigripes). Biological Conservation 89:121-129.

BurnhaM, K.P., AND D.R. ANDERSON. 2002. Model selection and multi-model inference. Springer Verlag, Inc., New York, NY.

Campbell, T.M., III, D.E. Biggins, S.C. ForRest, and T.W. CLARK. 1985. Spotlighting as a method to locate and study black-footed ferrets. Pages 24.1-24.7 in S.H. Anderson and D.B. Inkley, editors, Proceedings of the Black-footed Ferret Workshop. Wyoming Game and Fish Department, Cheyenne, WY.

ClaRK, T.W. 1989. Conservation biology of the black-footed ferret. Wildlife Preservation Trust Special Scientific Report No. 3.

Clark, T.W., T.M. Campbell III, M.H. Schroeder, and L. Richardson. 1983. Handbook of methods for locating black-footed ferrets. Wyoming Bureau of Land Management Wildlife Technical Bulletin No. 1.

De Solla, S.R., R. Bonduriansky, and R.J. Brooks 1999. Eliminating autocorrelation reduces biological relevance of home range estimates. Journal of Animal Ecology 68:221-234.

Fagerstone, K.A. 1987. Black-footed ferret, long-tailed weasel, short-tailed weasel, and least weasel. Pages 549-573 in M. Novak, J.A. Baker, M.E. Obbard, and B. Malloch, editors, Wild furbearer management and conservation in North America. Ontario Ministry of Natural Resources.
Fagerstone, K.A., and D.E. Biggins. 2011. Black-footed ferret areas of activity during late summer and fall at Meeteetse, Wyoming. Journal of Mammalogy 92: 705-709.

Fagerstone, K.A., And B.E. Johns. 1987. Transponders as permanent identification markers for domestic ferrets, black-footed ferrets, and other wildlife. Journal of Wildlife Management 51:294-297.

Ferguson, S.H., and S. Lariviere. 2004. Is mustelid life history different? Pages 2-19 in D.J. Harrison, A.K. Fuller, and G. Proulx, editors, Martens and fishers (Martes) in human-altered environments: an international perspective. Kluwer Academic Publishers, Norwell, MA.

Forrest, S.C., D.E. Biggins, L. RichaRdSON, T.W. Clark, T.M. Campbell III, K.A. Fagerstone, and E.T. THORNE. 1988. Population attributes for the blackfooted ferret (Mustela nigripes) at Meeteetse, Wyoming, 1981-1985. Journal of Mammalogy 69:261-273.

Forrest, S.C., T.W. Clark, L. Richardson, and T.M. CAMPBELL III. 1985. Black-footed ferret habitat: some management and reintroduction considerations. Wyoming Bureau of Land Management Wildlife Technical Bulletin No. 2.

Gannon, W.L., R.S. Sikes, And The Animal Care and Use Committee of The American Society of Mammalogists. 2007. Guidelines of the American Society of Mammalogists for the use of wild mammals in research. Journal of Mammalogy 88: 809-823.

Gehring, T.M., and R.K. Swihart. 2004. Home range and movements of long-tailed weasels in a landscape fragmented by agriculture. Journal of Mammalogy 85:138-145

Gese, E.M., D.E. Andersen, and O.J. Rongstad. 1990 Determining home range size of resident coyotes from point and sequential locations. Journal of Wildlife Management 54:501-506.

Henderson, F.R., P.F. Springer, and R. Adrian. 1969. The black-footed ferret in South Dakota. South Dakota Game, Fish and Parks Technical Bulletin No. 4.

Hillman, C.N., and T.W. Clark. 1980. Mustela nigripes. Mammalian Species 126:1-3.

Hillman, C.N., R.L. Linder, and R.B. DahlgRen. 1979. Prairie dog distribution in areas inhabited by blackfooted ferrets. American Midland Naturalist 102: $185-187$.

Hooge, PN. B. Eichenlaub, and E. Solomon. 1999. The Animal Movement Program. Alaska Biological Science Center, U.S. Geological Survey, Anchorage, AK.

JaCHOWSKi, D.S., AND J.M. LOCKHART. 2009. Reintroducing the black-footed ferret Mustela nigripes to the Great Plains of North America. Small Carnivore Conservation 41:58-64.

Jachowski, D.S., J.J. Millspaugh, D.E. Biggins, T.M Livieri, and M.R. Matchett. 2010. Home-range size and spatial organization of black-footed ferrets Mustela nigripes in South Dakota, USA. Wildlife Biology 16:1-11.

Livieri, T.M. 2006. Ten-year history of the Conata Basin black-footed ferret population: 1996-2005. Prairie Wildlife Research, Wall, SD

2007. Black-footed ferret spatial use of prairie dog colonies in South Dakota. Master's thesis, University of Wisconsin-Stevens Point, Stevens Point, WI.

LOCKharT, J.M., E.T. Thorne, AND D.R. GOBER. 2006. A historical perspective on recovery of the black-footed 
ferret and the biological and political challenges affecting its future. Pages 6-19 in J.E. Roelle, B.J. Miller, J.L. Godbey, and D.E. Biggins, editors, Recovery of the black-footed ferret-progress and continuing challenges. U.S. Geological Survey Scientific Investigations Report 2005-5293.

Miller, B., R.P. Reading, and S. Forrest. 1996. Prairie night: black-footed ferrets and the recovery of endangered species. Smithsonian Institution Press, Washington, DC.

Moнr, C.O. 1947. Table of equivalent populations of North American small mammals. American Midland Naturalist 37:223-249.

Odum, E.P., AND E.J. Kuenzler. 1955. Measurement of territory and home range size in birds. Auk 72: 128-137.

PowELL, R.A. 1979. Mustelid spacing patterns: variations on a theme by Mustela. Zeitschrift für Tierpsychologie 50:153-165.

.1994. Structure and spacing in Martes populations. Pages 101-121 in S.W. Buskirk, A.S. Harestad, M.G. Raphael, and R.A. Powell, editors, Martens, sables, and fishers: biology and conservation. Cornell University Press, Ithaca, NY.

REYNOLDS, T.D., AND J.W. LAUNDRE. 1990. Time intervals for estimating pronghorn and coyote home ranges and daily movements. Journal of Wildlife Management 54:316-322.

Richardson, L., T.W. Clark, S.C. Forrest, and T.M. CAMPBELL III. 1987. Winter ecology of black-footed ferrets (Mustela nigripes) at Meeteetse, Wyoming. American Midland Naturalist 117:225-239.

Rondinini, C., V. Ercoli, and L. Boitani. 2006. Habitat use and preference by polecats (Mustela putorius $\mathrm{L}$.) in a Mediterranean agricultural landscape. Journal of Zoology 269:213-219.

SANDELL, M. 1989. The mating tactics and spacing patterns of solitary carnivores. Pages 164-182 in J.L. Gittleman, editor, Carnivore behavior, ecology, and evolution. Volume 1. Cornell University Press, Ithaca, NY.

Seaman, D.E., J.J. Millspaugh, B.J. Kernohan, G.C. Brundige, K.J. Raedeke and R.A. Gitzen. 1999. Effects of sample size on kernel home range estimates. Journal of Wildlife Management 63:739-747.

ShaPIRO, S.S., AND M.B. WiLK. 1965. An analysis of variance test for normality (complete samples). Biometrika 52:591-611.

StoneberG, R. 1996. Implanted microchips used to individually identify black-footed ferrets in Montana. Prairie Naturalist 28:163-168.

Swihart, R.K., and N.A. SLade. 1997. On testing for independence of animal movements. Journal of Agricultural, Biological and Environmental Statistics 2:48-63.

Tileston, J.V., And R.R. Lechleitner. 1966. Some comparisons of the black-tailed and white-tailed prairie dogs in north-central Colorado. American Midland Naturalist 75:292-316.

Worton, B.J. 1989. Kernel methods for estimating the utilization distribution in home-range studies. Ecology 70:164-168.

Zar, J.H. 1996. Biostatistical analysis. 3rd edition. Prentice Hall, Upper Saddle River, NJ.

Received 21 June 2011 Accepted 13 February 2012 